\title{
How well can we parameterize past accumulation rates in polar ice sheets?
}

\author{
Eric J. Steig \\ Institute of Arctic and Alpine Research, University of Colorado, Boulder, CO 80309-0450, U.S.A.
}

\begin{abstract}
An important component of models of the cryosphere is the calculation of accumulation rates over polar ice sheets. As a first-order approximation, many models rely on the assumption that temperature is the main controlling factor for precipitation. However, compilation of available ice-core data, including a new core from Taylor Dome, East Antarctica, suggests that precipitation is significantly decoupled from temperature for a large proportion of both the Greenland and Antarctic ice sheets. While the estimated glacial-to-interglacial change in temperature does not differ greatly among ice cores from each ice sheet, the estimated change in accumulation rate varies by more than a factor of 2. A simple vapor-pressure parameterization gives reasonable estimates of accumulation in the ice-sheet interior, but this is not necessarily the case close to the ice-sheet margin, where synoptic weather systems are important.
\end{abstract}

\section{INTRODUCTION}

In recent years, much effort has been devoted to the development of models that can accurately simulate modern accumulation patterns over polar ice sheets (e.g. Fortuin and Oerlemans, 1990; Bromwich and others, 1993; Fastook and Prentice, 1994). There has also been an effort to estimate the magnitude of accumulation-rate changes under future greenhouse-warming scenarios (e.g. Huybrechts and Oerlemans, 1990; Verbitsky and Saltzman, 1995; Verbitsky and Oglesby, 1995). Somewhat less emphasis has been placed on the calculation of accumulation under past climate conditions. Such research is important because accumulation is one of the determining factors in ice-sheet response to climate. Although numerical models of former ice-sheet configurations have been developed, comparison of these results with glacial-geologic data (e.g. Stuiver and others, 1981; Denton and others, 1989; Bromwich and others, 1991; Huybrechts, 1993) does not provide sufficient validation alone (Oreskes and others, 1994).

Accumulation rate is one of the fundamental parameters available from analysis of ice cores in polar regions. As the areal coverage and quality of ice-core records increases, it becomes increasingly worthwhile to consider the extent of agreement between model estimates and empirical measurements. In this paper, common approaches to the parameterization of accumulation rates on polar ice sheets are reviewed, and these approaches are discussed in the light of ice-core data from both hemispheres. Such comparisons provide an important test of the fidelity of numerical models.

\section{PARAMETERIZATION OF ACCUMULATION IN NUMERICAL MODELS}

The most straightforward approach to modeling accumulation over polar ice sheets is to assume that precipitation is primarily thermodynamically controlled. That is, the amount of water precipitated is proportional to the moisture-carrying capacity of the air mass, according to the relationship between temperature $(T)$ and the saturation vapor pressure $(P)$ over ice, which follows an Arrhenius relationship:

$$
P=\alpha_{e}^{(-\beta / T)}+\mathrm{c}
$$

where $\alpha, \beta$ and c are empirical constants. Note that for polar ice sheets, other than very near the margin, it may be assumed that ablation is minimal and that accumulation $\approx$ precipitation.

Over large parts of Antarctica there is a strong correlation between accumulation rate, $P$ and $T$ above the surface inversion layer (Robin, 1977). The correlation can be improved further by accounting empirically for orographic effects. For example, Fastook and Prentice (1994) use the observed present-day Antarctic accumulation pattern to determine a function relating accumulation rate $(\dot{b})$ to the average surface slope $(S)$ and the saturation vapor pressure:

$$
\dot{b}=\mathrm{A} P+\mathrm{B} S+\mathrm{C}
$$

where, A, B and C are empirical constants. Fortuin and Oerlemans (1990) and Huybrechts $(1993,1994)$ take a more direct approach, expressing $\dot{b}$ simply as an empirical function of mean annual temperature:

$$
\dot{b}=0.78+2.525 \times 10^{-2} T+2.225 \times 10^{-4} T^{2} .
$$

In modeling modern accumulation rates over the Greenland ice sheet, Bromwich and others (1993) take a considerably more sophisticated approach, using empirical measures of atmospheric dynamics:

$$
\dot{b}=\mathrm{A} P V_{\mathrm{v}}+\mathrm{B} P V_{\mathrm{G}} \nabla H
$$

where $H$ is the terrain height, and $V_{\mathrm{G}}$ and $V_{\mathrm{v}}$ are parameterizations for the geostrophic- and vertical-wind velocity, respectively. In Equation (4), as in Equations (2) and (3), P may be considered an empirical function of $T$.

Clearly, if we wish to apply models such as those given 
above to past climate conditions, we will be limited by the assumption that the empirically derived coefficients (and in the case of Equation (4), the atmospheric dynamics) remain constant. Because of this inherent limitation of empirical models, we may consider turning to more sophisticated atmospheric general circulation models (GCMs), which explicitly solve for synoptic-scale variables such as storm frequency. Current-generation GCMs, however, are notoriously poor at simulating precipitation in polar regions, tending to produce higher-than-observed accumulation rates over both Greenland and Antarctica Gates and others, 1990; Tzeng and others, 1993; Bromwich and others, 1994). The discrete nature of precipitation events is in contrast to such climate variables as pressure and temperature, for which long-term annual average values provide resolution sufficient for many applications. This problem has not been resolved, but must, in part, be a consequence of the inability of these models to simulate adequately cyclonic systems (Bromwich and others, 1991; Connolley and Cattle, 1994) and to incorporate fully the seasonal cycle (Joussaume and Jouzel, 1993; Charles and others, 1994).

In summary, we are currently limited to "low-order" empirical models, which can be tuned to fit observed accumulation patterns to an arbitrary degree of accuracy, but are limited in their ability to simulate temporal changes; or to "high-order" GCMs that are currently unsatisfactory for modeling polar precipitation. A possible way around this dilemma is to assume that the changes in the climate variables predicted by a GCM are more precise than the absolute values predicted (e.g. Kutzbach and Guetter, 1986; COHMAP members, 1988; Verbitsky and Saltzman, 1995). However, such an approach still requires empirical observations for scaling the model-output data. For the immediate future at least, we will be reliant on empirical models, and it is therefore important to consider the extent of agreement between the predictions of such models and the paleoclimate record from ice cores.

\section{DATA}

In reviewing empirical measurements of accumulation rate, the transition from the Last Glacial Maximum (LGM) (about $20 \mathrm{ka} \mathrm{BP}$ ) to the Holocene is considered, since it represents the largest climate change for which there is a reasonable ice-core dataset available.

For the Vostok ice core (Fig. 1), East Antarctica, Lorius and others (1985) estimated accumulation rates over the last 150000 years by assuming, as in the models discussed above, that accumulation is thermodynamically controlled. The temperature history is taken from isotopic measurements $\left(\delta^{18} \mathrm{O}\right.$ or $\left.\delta \mathrm{D}\right)$ according to:

$$
T=\mathrm{a} \delta+\mathrm{b}
$$

where $T$ is the temperature above the surface inversion layer, and a and b are constants. Taking into account changes in the isotopic content of sea water in the calculation of $T$, and using a $=9 \%{ }^{\circ} \mathrm{C}^{-1}$ for $\delta \mathrm{D}$ (Jouzel and others, 1996), this parameterization gives a LGM lowering of accumulation at Vostok to about $50 \%$ of the present-day value. It should be noted that borehole temperature measurements at Vostok (Salamatin and others, 1994) suggest that the assumption of a constant $\delta-T$ relationship is probably reasonable for the East Antarctic interior. That the

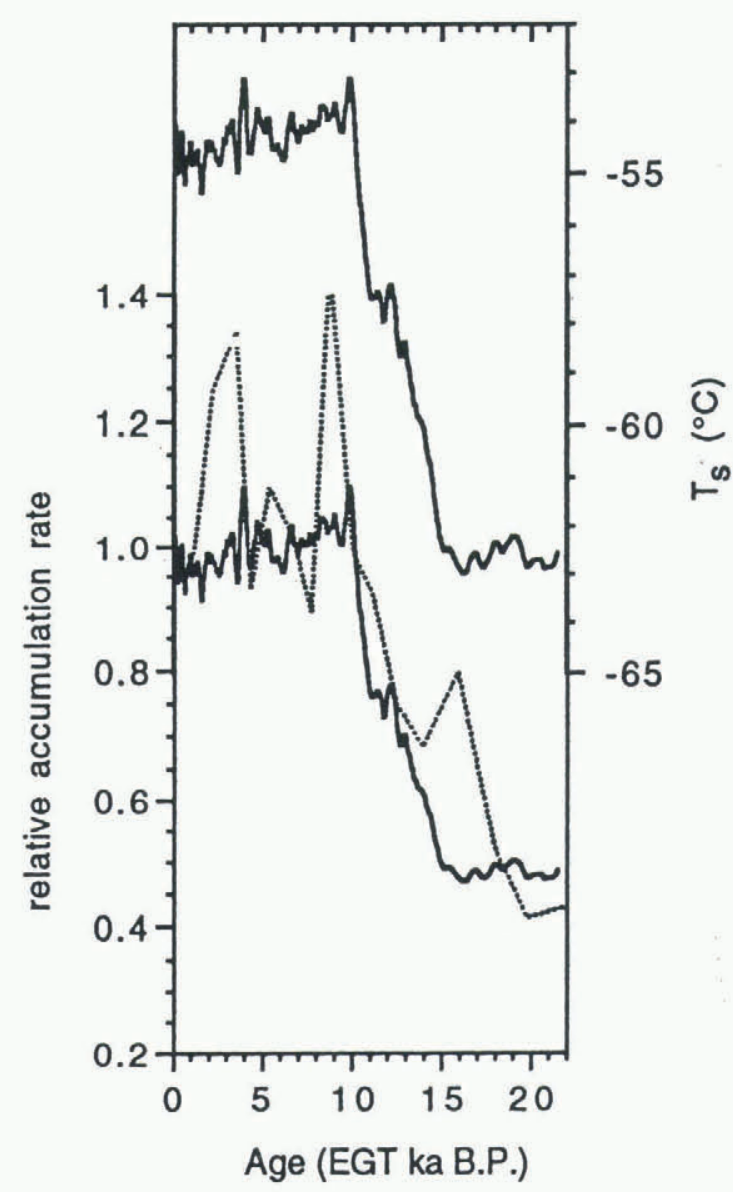

Fig. 1. Upper line: surface temperature at Vostok, Antarctica, over the last $25 \mathrm{ka}$ on the "extended glaciological time-scale" (EGT) (Jouzel and others, 1993). Lower solid line: the relative accumulation rate (normalized to a modern value of 1) calculated from the vapor-pressure relationship (Lorius and others, 1985). Dolted line: the relative accumulation rate calculated from ${ }^{10}$ Be concentrations (Raisbeck and others, 1987).

original Vostok time-scale (Lorius and others, 1985) compares favorably with recent and more accurate determinations of the Vostok age-depth relationship (Jouzel and others, 1993; Sowers and others, 1993; Sowers and Bender, 1995) supports the validity of this parameterization, at least in central East Antarctica. It is further supported by ${ }^{10} \mathrm{Be}$ measurements in the Vostok core, which show a 50\%-60\% decrease in concentration following the LGM (Raisbeck and others, 1987; Jouzel and others, 1989). A strong inverse correlation between snow accumulation and ${ }^{10} \mathrm{Be}$ concentration is expected because ${ }^{10} \mathrm{Be}$ deposition at low-accumulation-rate sites such as Vostok is predominantly by dry fallout (Raisbeck and Yiou, 1985; Yiou and others, 1985; Lorius and others, 1989; Steig and others, in press); also the polar atmospheric concentration of ${ }^{10} \mathrm{Be}$ is unlikely to have changed by more than a few percent over the last $20 \mathrm{ka}$ (Steig and others, 1996).

The best estimates of accumulation rates in Greenland are derived from combined ice-flow model/layer-thickness measurements on the U.S. and European ice cores at Summit (GISP2 and GRIP; respectively). Dahl-Jensen and others (1993) calculated that accumulation rates at the GRIP site were about $30 \%$ of present-day values at the LGM; Cutler and others (1995) and Cuffey and Close (in press) give very similar estimates of the LGM accumulation rate at GISP2 (30 km away). 
For many other Greenland ice cores, particularly those closer to the coast, the estimated LGM-Holocene change in accumulation rate is larger than at Summit. Depending on the time-scale adopted and the flow-model assumptions employed, the LGM accumulation rate at Camp Century, northwest Greenland, was as low as $20 \%$ of the Holocene value (Reeh, 1990). Similar estimates have been obtained for the southwestern Greenland site, Dye3 (Reeh and others, 1985; Reeh, 1990), while a LGM lowering of accumulation to as little as $10 \%$ of present values was calculated for the Devon Ice Cap, eastern Arctic Canada (Paterson and Waddington, 1984).

In Antarctica, as in Greenland, warmer, less continental sites appear to have experienced a somewhat larger change in accumulation rates during the LGM-Holocene transition. While accumulation-rate histories at Dome Cirque and Dome B (interior East Antarctica) are apparently similar to those at Vostok (Jouzel and others, 1989; 1995), estimates from ${ }^{10}$ Be measurements (Beer and others, 1987) and from recent refinements to the age depth relationship (Hammer and others, 1994) suggest that accumulation rates at Byrd Station, West Antarctica, during the LGM were at most $40 \%$ of Holocene values. At Taylor Dome (Fig. 2), just inland of the Transantarctic Mountains in East Antarctica (Grootes and Steig, 1992; Waddington and others, 1993; Grootes and others, 1994), there is an even greater LGMHolocene contrast: both preliminary flow-model calculations and ${ }^{10} \mathrm{Be}$ measurements (Steig, 1996) indicate that the accumulation rate during the LGM was at most $20-25 \%$ of the Holocene value.

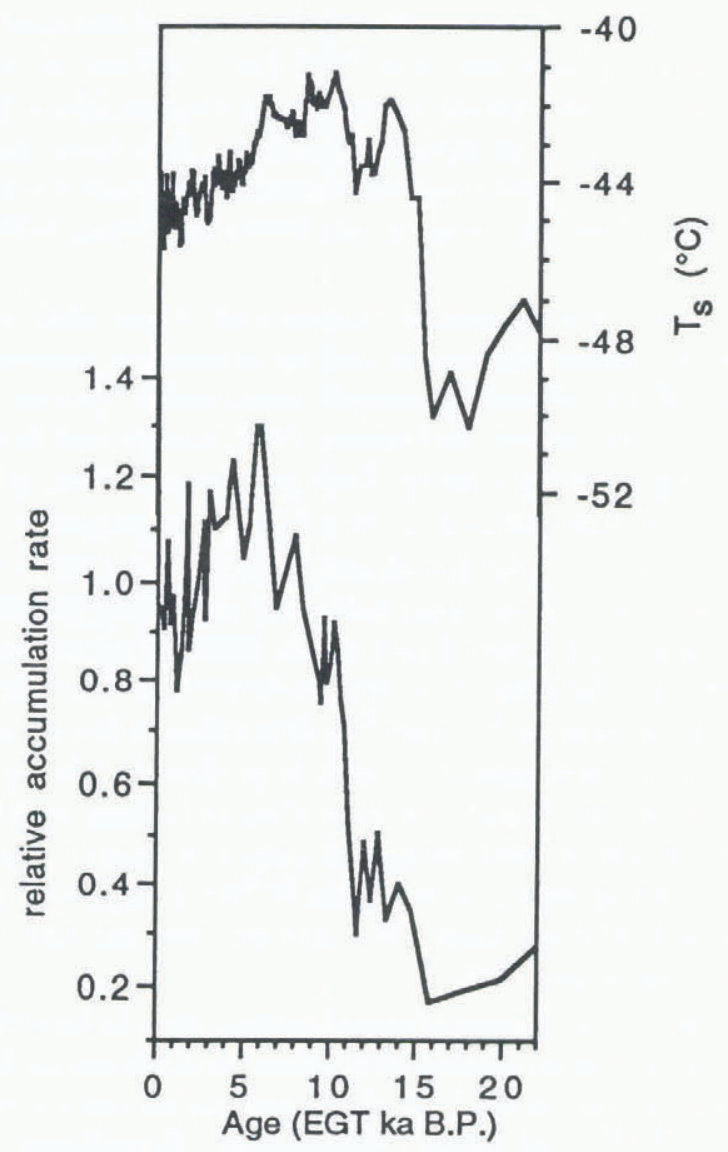

Fig. 2. Upper line: surface temperature at Taylor Dome, Antarctica, calculated from $\delta^{18} \mathrm{O}$ measurements at Taylor Dome, assuming that $\delta^{18} \mathrm{O}=8 \delta \mathrm{D}+10$ and $\partial \delta \mathrm{D} / \partial \mathrm{T}=9 \%{ }^{\circ} \mathrm{C}$ (after Jouzel and others, 1996). Lower line: relative accumulation rate from ${ }^{10}$ Be measurements (Steig, 1996).

\section{COMPARISON OF MODEL RESULTS AND ICE-CORE DATA}

Analysis of borehole temperature measurements in the Summit cores (Cuffey and others, 1994, 1995; Johnsen and others, 1995) reveal that the slope of the $\delta^{18} \mathrm{O}$-T relationship (the value of a in Equation (5)) in central Greenland is much lower $(\sim 0.2)$ for the LGM-Holocene transition than the modern value of about 0.6. Thus, we cannot use the same parameterization for the Summit cores as given above for Vostok. However, assuming that the thermodynamic relationship applies at Summit, the surface-temperature history derived from borehole analyses yields an accumulation profile that is highly compatible with the inferred history from ice-flow modeling (Cuffey and Clow, in press). These results are shown in Figure 3. The assumption has been made that accumulation is most highly correlated with the temperature above the surface inversion layer $T_{\mathrm{i}}(\mathrm{K})$, which can be estimated from the surface temperature $T_{\mathrm{s}}$ (Fortuin and Oerlemans, 1990):

$$
T_{\mathrm{i}}=0.67\left(T_{\mathrm{s}}\right)+88.9 .
$$

Given the strong apparent correlation between accumulation and temperature at both Summit and at Vostok, it is tempting to conclude that accumulation rates over polar ice sheets can generally be parameterized in terms of a simple thermodynamic relationship (Equation (1)). However, results from the Taylor Dome core bring this into question. As illustrated in Figure 2, accumulation at Taylor Dome

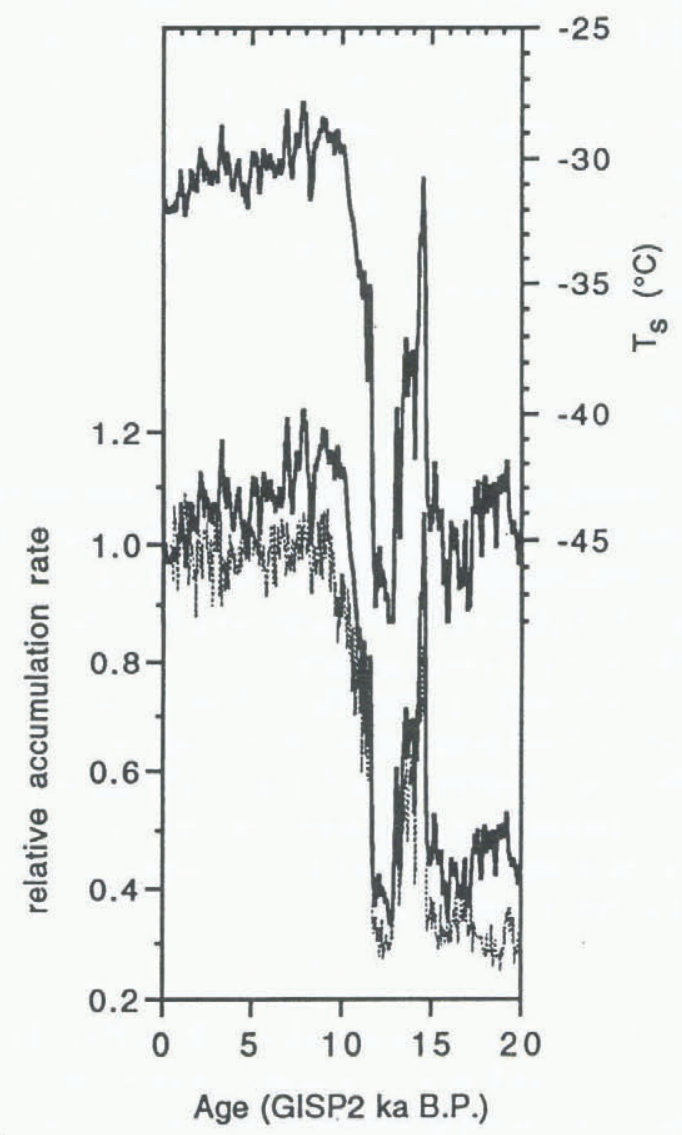

Fig. 3. Upper line: surface temperature at Summit, Greenland, calculated from borehole temperatures and $\delta^{18} \mathrm{O}$ values (Cuffey and others, 1995). Lower solid line: relative accumulation rate calculated from the vapor-pressure relationship (Lorius and others, 1985). Dotted line: flow-model calculations of accumulation (Cuffey and Clow, in press). 
does not parallel the temperature history inferred from $\delta^{18} \mathrm{O}$ analyses. Although Taylor Dome appears to have experienced a somewhat different temperature history than did Vostok, it is likely that the $\delta-T$ relationship is similar at both sites, given the similarity in the magnitude and timing of the LGM-Holocene shift in stable-isotope values (Grootes and others, 1994) and the probable similarity in moisture provenance (Petit and others, 1991; Mayewski and others, 1996). The noticeable differences between the inferred temperature and accumulation histories at Taylor Dome strongly imply that non-thermal effects, such as the degree of storminess, must play a role in determining accumulation at Taylor Dome. Although the differences are not as dramatic, a similar argument applies to the Byrd results, and probably to the Camp Century, Dye3 and Devon Island cores: in general, the magnitude of temperature change during the LGM-Holocene transition is comparable among cores on each ice sheet, but the estimated accumulation-rate change varies by at least a factor of 2 .

A more favorable comparison between data and model results can be obtained if empirical fits to the modern distribution of accumulation are used, rather than the simple parameterization given in Equation (1). Common to each of the models discussed above (Equations (2) and (3)) is that the sensitivity of accumulation rate to temperature change decreases with distance from the ice-sheet margin, bearing in mind that the mean annual temperature $(T)$ in all three models is a function of latitude and altitude. (That is, the derivatives $\partial \dot{b} / \partial T$ of each expression for $\dot{b}$ increase with $T$ over an appropriate range of temperatures.) For example, if we postulate a decrease in $T$ of $10^{\circ} \mathrm{C}$ and assume that all other parameters remain constant, we calculate from the Huybrechts (1993) model (Equation (3)) that a site with a current $T$ of $-30^{\circ} \mathrm{C}$ (e.g. Byrd Station) would experience a drop in accumulation to about $50 \%$ of present-day values. A site with current $T$ of $-55^{\circ} \mathrm{C}$ (e.g. Vostok) would experience a much smaller (about 10\%) decrease in accumulation. The values given by Fastook and Prentice (1994) for the coefficients in Equation (1) yield similar results, as does Bromwich and others' (1993) model for Greenland. Note, however, that while the sign of the calculated difference in response is correct, these parameterizations greatly overestimate the difference among ice-core sites, suggesting that the assumption of constant coefficients is invalid.

\section{CONGLUSIONS}

In general, it appears that the accumulation history of the interior of large ice sheets is quite reasonably approximated by a simple thermodynamic relationship:

$$
\frac{\partial \dot{b}}{\partial T} \propto \frac{\partial P}{\partial T} .
$$

Although this conclusion is in agreement with the early work of Robin (1977) and Lorius and others (1985) in Antarctica, it is in marked contrast to that of Kapsner and others (1994), who suggested that atmospheric circulation, rather than temperature, drives accumulation-rate variations at Summit, Greenland.

Away from the ice-sheet interior, however, neither the simple relationship given above, nor empirical parameterizations of the distribution of accumulation under modern conditions, can be used to determine reliably past accumu- lation rates. Results from ice cores such as Taylor Dome and Byrd in Antarctica, and Camp Century and Dye3 in Greenland, suggest that changes in atmospheric circulation, and possibly other factors, must play a major role in determining regional accumulation patterns.

Finally, it is important to note that empirical models such as those of Huybrechts (1993) and Fastook and Prentice (1994), in which $T$ is the only free variable, tend to overestimate the difference in sensitivity of interior and coastal areas with regard to accumulation rate during colder-thanpresent climates. Inaccuracies of this nature suggest that numerical models of ice-sheet configuration that use simple thermodynamic relationships in their parameterization of accumulation rate must be treated with caution.

\section{REFERENCES}

Beer, J. and 8 others. 1987. ${ }^{10}$ Be measurements on polar ice: comparison of Arctic and Antarctic records. Nucl. Instrum. Methods Phys. Res., Ser. B. 29 (1), 203-206.

Bromwich, D. H., D. H. Elliot, D. M. Harwood and P. -N. Webb. 1991. The Antarctic glacial geologic record and GCM modeling: a test. In Weller. G., C. L. Wilson and B. A. B. Severin, eds. International Conference on the Role of the Polar Regions in Global Change: proceedings of a conference held June II-15, 1990 at the Liviersity of Alaska Fairbanks. Vol. II. Fairbanks. AK. University of Alaska. Geophysical Institute/Center for Global Change and Arctic System Research. 508516.

Bromwich, D. H., F. M. Robasky, R. A. Keen and J. F. Bolzan. 1993. Modeled variations of precipitation over the Greenland ice sheet. 7. Climate. 6 (7), $1253-1268$.

Bromwich, D. H., R. -Y. Tzeng and T. R. Parish. 1994. Simulation of the modern Arctic climate by the NC.AR CCMI. f. Climate, 7 7), 1050-1069.

Charles, C. D., R. Rind, J. Jouzel, R. D. Koester and R. G. Fairbanks. 1994. Glacial-interglacial changes in moisture sources for Greenland: influences on the ice core record of climate. Science, 263 (5146), 508-511.

COHMAP members. 1988. Climatic changes of the last 18,000 years: observations and model simulations. Science, 241 (4869), 1043-1052.

Connolley, W. M. and H. Cattle. 1994. The Antarctic climate of the UK.MO unified model. Antarct. Sci., 6 1), $115-122$.

Cuffey, K. M. and G. D. Clow. In press. Temperature, accumulation and ice sheet elevation in central Greenland through the last deglacial transition. J. Geophys. Res..

Cuffey, K. M., R. B. Alley, P. M. Grootes, J. M. Bolzan and S. Anandakrishnan. 1994. Calibration of the $\delta^{18} \mathrm{O}$ isotopic paleothermometer for central Greenland, using borehole temperatures. J. Glaciol., 40 (135), $341-349$.

Cuffey, K. M., G. D. Clow, R. B. Alley, M. Stuiver, E. D. Waddington and R.W. Saltus. 1995. Large Arctic temperature change at the WisconsinHolocene glacial transition. Science, 270 (5235), $45.5-458$.

Cutler, N. N., C. F. Raymond, E. D. Waddington, D. A. Meese and R. B. Alley. 1995. The effect of ice-sheet thickness change on the accumulation history inferred from GISP2 layer thicknesses. Ann. Glaciol., 21. 26-32.

Dahl-Jensen, D., S. J. Johnsen, C. U. Hammer, H. B. Clausen and J. Jouzel. 1993. Past accumulation rates derived from observed annual layers in the GRIP ice core from Summit, central Greenland. In Peltier, W.R. ed. Ice in the climate system. Berlin, etc., Springer-Verlag, 517-532. (NATO ASI Series I: Global Environmental Change 12.

Denton, G. H., J. G. Bockheim, S. C. Wilson and M. Stuiver. 1989. Late Wisconsin and Early Holocene glacial history, inner Ross embayment, Antarctica. Ouat. Res., 31 2, 151-182.

Fastook, J. L. and M. Prentice. 1994. A finite-element model of Antarctica: sensitivity test for meteorological mass-balance relationship. f. Glaciol., 40 (134), 167-175.

Fortuin, J. P. F. and J. Oerlemans. 1990. Parameterization of the annual surface temperature and mass balance of Antarctica. Ann. Glaciol., 14, 7884.

Gates, W. L., P. R. Rowntree and Q. -C. Zeng. 1990. Validation of climate models. In Houghton, J. T., G. J. Jenkins and J.J. Ephraums, eds. Climate change: the IPCC scientific assessment. Cambridge, etc., Cambridge University Press, 93-130.

Grootes, P. M. and E.J. Steig. 1992. Taylor Dome ice-core study. Antart. J. L.S., $27(5), 57-58$.

Grootes, P. M., E.J. Steig and M. Stuiver. 1994. Taylor Ice Dome study 1993-1994: an ice core to bedrock. Antarcl. J. L.S., 29 5), 79-81.

Hammer, C. U., H. B. Clausen and C. C. Langway, Jr. 1994. Electrical conductivity method (ECM) stratigraphic dating of the Byrd Station ice core, Antarctica. Ann. Glaciol., 20,115 120. 
Huybrechts, P. 1993. Glaciological modelling of the Late Cenozoic East Antarctic ice sheet: stability of dynamism? Geogr. Ann., 75A (4), 221-238.

Huybrechts, P. 1994. Formation and disintegration of the Antarctic ice sheet. Ann. Glaciol., 20, 336-340.

Huybrechts, P. and J. Oerlemans. 1990. Response of the Antarctic ice sheet to future greenhouse warming. Climate Dyn., 5(2), 93-102.

Johnsen, S. J., D. Dahl-Jensen, W. Dansgaard and N. S. Gundestrup. 1995. Greenland paleotemperatures derived from GRIP borehole temperature and ice core isotope profiles. Tellus, Ser, B, 47 (5), 624-629.

Joussaume, S. and J. Jouzel. 1993. Paleoclimatic tracers: an investigation using an atmospheric general circulation model under ice age conditions. 2. Water isotopes. 7. Geophys. Res., 98 (D2), 2807-2830.

Jouzel, J. and 9 others. 1989. A comparison of deep Antarctic ice cores and their implications for climate between 65,000 and 15,000 years ago. Quat. Res., 31 (2), 135-150.

Jouzel, J. and 16 others. 1993. Extending the Vostok ice-core record of palaeoclimate to the penultimate glacial period. Nature, 364 (6436), 407-411.

Jouzel, J. and 11 others. 1995. Two-step shape and timing of the last deglaciation. Climate Dyn., 11 (3), 151-161.

Jouzel, J. and 13 others. 1996. Climatic interpretation of the recently extended Vostok ice core records. Climate Dyn., 12 8), $513-521$.

Kapsner, W. R., R. B. Alley, C. A. Shuman, S. Anandakrishnan and P. M. Grootes. 1995. Dominant influence of atmospheric circulation on snow accumulation in Greenland over the past 18,000 years. Nature, 373 (6509), $52-54$.

Kutzbach, J. E. and P.J. Guetter. 1986. The influence of changing orbital parameters and surface boundary conditions on climate simulations for the past 18,000 years. J. Atmos. Sci., 43 16), 1726-1759.

Lorius, C. and 6 others. 1985. A 150,000-year climatic record from Antarctic ice. Nature, 316 (6029), 591-596.

Lorius, C., G. Raisbeck, J. Jouzel and D. Raynaud. 1989. Long-term environmental records from Antarctic ice cores. In Oeschger, H. and C. C. Langway, Jr, eds. The environmental record in glaciers and ice sheets. Chichester, etc., John Wiley and Sons, 343-361.

Mayewski, P.A. and 13 others. 1996. Climate change during the last deglaciation in Antarctica. Science, 272 (5268), 1636-1638.

Oreskes, N., K. Shrader-Frechette and K. Belitz. 1994. Verification, validation, and confirmation of numerical models in the earth sciences. Science, 263 (5147), 641-646.

Paterson, W. S. B. and E. D. Waddington. 1984. Past accumulation rates at Camp Century and Devon Island, deduced from ice-core measurements. (Abstract.) Ann. Glaciol., 5, 222223.

Petit, J. R., J.W. C. White, N.W. Young, J. Jouzel and Ye. S. Korotkevich. 1991. Deuterium excess in recent Antarctic snow. F. Geophys. Res., 96 (D3), 5113-5122.

Raisbeck, G. M. and F. Yiou. $1985 .{ }^{10} \mathrm{Be}$ in polar ice and atmospheres. Ann. Glaciol., 7, $138-140$.

Raisbeck, G. M., F. Yiou, D. Bourles, C. Lorius, J. Jouzel and N. I. Barkov. 1987. Evidence for two intervals of enhanced ${ }^{10} \mathrm{Be}$ deposition in Antarctic ice during the last glacial period. Nature, 326 (6110), 273-277.
Reeh, N. 1990. Past changes in precipitation rate and ice thickness as derived from age-depth profiles on ice-sheets: application to Greenland and Canadian Arctic ice core records. In Bleil, U. and J. Thiede, eds. Geological history of the polar oceans: Arctic versus Antarctic. Dordrecht, etc., Kluwer Academic Publishers, 255 - 271. (NATO ASI Series C: Mathematical and Physical Sciences 308.

Reeh, N., S. J. Johnsen and D. Dahl-Jensen. 1985. Dating the Dye 3 deep ice core by flow model calculations. In Langway, C. C., Jr, H. Oeschger and W. Dansgaard, eds. Greenland ice core: geophysics, geochemistry, and the environment. Washington, DC, American Geophysical Union, 56- 65. (Geophysical Monograph 33.

Robin, G, de Q. 1977. Ice cores and climatic change. Philos. Trans. R. Soc, London, Ser. B., 280 (972), 143-168.

Salamatin, A. N., V.Ya. Lipenkov and K. V. Blinov. 1994. Vostok (Antarctica) climate record time-scale deduced from the analysis of a boreholetemperature profile. Ann. Glaciol., 20, 207-214.

Sowers, T. and M. Bender. 1995. Climate records covering the last glaciation. Science, 269 (5221), $210-214$.

Sowers, T. and 7 others. 1993. A 135,000-year Vostok-SPECMAP common temporal framework. Paleoceanography, 8 6), 737-766.

Steig, E.J. 1996. Beryllium-10 in the Taylor Dome ice core: applications to Antarctic glaciology and paleoclimatology. (Ph.D. thesis, University of Washington.).

Steig, E. J., P.J. Polissar, M. Stuiver, P. M. Grootes and R. C. Finkel. 1996. Large amplitude solar modulation cycles of ${ }^{10} \mathrm{Be}$ in Antarctica: implications for atmospheric mixing processes and interpretation of the ice core record. Geophys. Res. Lell., 23 (5), 523-526.

Steig, E.J., P. Polissar and M. Stuiver. In press. Cosmogenic isotope concentrations at Taylor Dome, Antarctica. Antarct. 7. U.S.

Stuiver, M., G. H. Denton, T.J. Hughes and J. L. Fastook. 1981. History of the marine ice sheet in West Antarctica during the last glaciation: a working hypothesis. In Denton, G. H. and T. J. Hughes, eds. The last great ice sheets. New York, etc., John Wiley and Sons, 319-436.

Tzeng, R. -Y., D. H. Bromwich and T. R. Parish. 1993. Present-day Antarctic climatology of the NCAR community climate model version I. F. Climate, 6 (2), 205226.

Verbitsky, M.Ya. and R.J. Oglesby. 1995. The $\mathrm{CO}_{2}$-induced thickening/ thinning of the Greenland and Antarctic ice sheets as simulated by a GCM (CCMI) and an ice-sheet model. Climate Dyn., 11 (4), 247-253.

Verbitsky, M. Ya. and B. Saltzman. 1995. Behavior of the East Antarctic ice sheet as deduced from a coupled GCM/ice-sheet model. Geophys. Res. Lett., 22 (21), 2913-2916.

Waddington, E. D., D. L. Morse, P. M. Grootes and E. J. Steig. 1993. The connection between ice dynamics and paleoclimate from ice cores: a study of Taylor Dome, Antarctica. In Peltier, W. R., ed. Ice in the climate system. Berlin, etc., Springer-Verlag, 499-516. (NATO ASI Series I: Global Environmental Change 12.)

Yiou, F., G. M. Raisbeck, D. Bourles, C. Lorius and N. I. Barkov. $1985 .{ }^{10} \mathrm{Bc}$ in ice at Vostok during the last climatic cycle. Nature, 316 6029), 616617. 